материалам дел ввиду недостаточности фактов значимости и подлинности таких документов. Это связано с возможностью фальсифицировать продукты информатизации. Для того, чтобы установить юридическую значимость фактов, необходимо проводить соответствующую экспертизу по назначению суда. Помимо проведения экспертизы, для подачи в ходатайстве в качестве письменных доказательств документы, полученные с применением средств информатизации, необходимо зафиксировать у нотариуса.

Таким образом, в условиях быстроразвивающегося информационного общества, использование письменных доказательств в электронно-цифровом виде на гражданскопроцессуальных судебных разбирательствах набирают стремительные обороты. Проблема использования электронных документов в качестве доказательств остается одной из центральных в отрасли доказательственного права. Нам необходимо четко определить, к какому же виду следует отнести продукты информатизации в системе доказательств.

$$
* * *
$$

1. Бегичев А.В. Электронные доказательства и способы их фиксации нотариусом // Нотариус. 2014. N 5.

2. Ворожбит С.П. Электронные средства доказывания в гражданском и арбитражном процессе: Автореф. дис. канд. юрид. наук. СПб., 2011. С. 8.

3. Гройсберг А.И. Электронные доказательства в системе правосудия по гражданским делам // Вестник гражданского процесса. 2019. N 2.

4. Гражданский процессуальный кодекс Российской Федерации от 14.11.2002 N 138-Ф3 (ред. от 01.07.2021). [Электронный ресурс] КонсультантПлюс: справочно-правовая система / Режим доступ: / URL: http:// base.www.consultant.ru / (дата обращения 26.10.2021 г.).

\title{
Джангиров Н.И., Соловьева С.В. \\ Основные и специальные обязанности кредитных организаций в сфере противодействия легализации доходов, полученных преступным путем, и финансированию терроризма
}

\author{
ФГБОУ ВО СКФ РГУП \\ (Россия, Краснодар)
}

doi: 10.18411/trnio-11-2021-239

Научный руководитель: Соловьева С.В.

\section{Аннотация}

Легализация преступных доходов становится угрозой национальной безопасности любого государства, так как привлекает в страну преступные элементы. Деятельность профессиональных преступников присутствует во всех сферах экономики, но самым пострадавшим преступлением остается кредитно-финансовая система, которая служит основным каналом для движения незаконных средств. Кредитные организации являются одним из инструментов проведения кредитно-денежной политики, контроль и обеспечение их устойчивости стало одним из основных направлений в политики государства.

Ключевые слова: противодействие, терроризм, легализация доходов, кредитные организации, незаконный оборот, финансовые средства.

\section{Abstract}

The legalization of criminal proceeds becomes a threat to the national security of any state, as it attracts criminal elements to the country. The activities of professional criminals are present in all spheres of the economy, but the most affected crime remains the credit and financial system, which serves as the main channel for the movement of illegal funds. Credit organizations are one of the instruments of conducting monetary policy, monitoring and ensuring their stability has become one of the main directions in the state policy.

Keywords: counteraction, terrorism, money laundering, credit organizations, illegal trafficking, financial resources. 
Особую роль в финансовой системе государства занимают кредитные организации, через филиалы которых, в значительном большинстве случаев, осуществляется легализация финансовых активов, таких как: денежные средства, ценные бумаги, драгоценные металлы, имущество и др.

Изучение основных и специальных обязанностей кредитных организаций в части осуществления ими публично-правовых функций, актуально в настоящее время и представляет большой интерес у исследователей. Характеризуя основные правовые аспекты в области регулирования обязанностей банков, необходимо сформулировать наиболее полное определение отмыванию доходов и финансированию терроризма.

Под легализацией (отмыванием) доходов, полученных преступным путем понимается придание правомерного вида владению, пользованию или распоряжению денежными средствами или иным имуществом, полученными в результате совершения преступления.

Финансирование терроризма - это предоставление или сбор средств либо оказание финансовых услуг с осознанием того, что они предназначены для финансирования организации, подготовки и совершения хотя бы одного из преступлений, либо для обеспечения организованной группы, незаконного вооруженного формирования или преступного сообщества (преступной организации) финансовыми ресурсами.

На основании нормативно-законодательной базы в области финансового права, имеющейся в стране, а также с учетом международных требований и ратифицированных Конвенций, в России, как и во многих других государствах, установлен и продолжает формироваться режим государственного контроля и надзора за денежными операциями и сделками, которые проходят через финансово-кредитные и другие ведомства.

Вместе с тем, фактический режим мониторинга продолжает постоянно корректироваться, дополняться и изменяться в связи с возникновением новых терминов, сделок, схем ухода от государственного надзора. Исследование проблемы правового обеспечения государственного контроля на сегодняшний день представляет одну из важнейших задач при изучении современного законодательства в области регулирования деятельности финансово-кредитной системы и её стабильности.

Государственный контроль предполагает строгое выполнение персоналом банков своих основных обязанностей, суть которых заключена в обязательной процедуре проведения идентификации и информировании специальных контролирующих структур о подозрительных банковских операциях и сомнительных сделках, которые могут быть заключены в конкретном банковском учреждении.

При этом, строгое соблюдение инструкций и положений, а также ответственный подход сотрудников кредитных организаций имеют огромное значение в осуществлении государственного контроля в ходе исполнения кредитными организациями своих непосредственных обязанностей. Кроме того, в кредитных организациях, как и во всех остальных учреждениях, ведется учет и составляется отчетность, которая является основанием для составления и подачи сведений о сделках и операциях, именуемых в разряде подозрительных. Занятие ключевой роли банковских структур определяется теми задачами, которые стоят перед ними. Филиалы банков часто становятся целью преследования криминальных элементов, что в значительной степени определяется самой деятельностью финансово-кредитных организаций.

В современных условиях деятельность кредитных организаций в целом и работа всех его подразделений, в частности, направлена на клиента и удовлетворение его потребностей с целью завязывания с ним постоянных деловых отношений. Современные банковские продукты и банковский инструментарий предоставляют возможность юридическим фирмам разных направлений и населению повысить результативность взаимодействия с кредитными организациями, в том числе через онлайн-ресурсы, что создает определенные сложности для самих кредитных организаций и службы безопасности банков. Использование специальных сервисов, создаваемых в банковских структурах, обеспечивает сбор информации, а проанализировав собранные данные, делаются выводы о проведенных банковских операциях 
с целью информирования Росфинмониторинга о подозрительных операциях и сделках.

Поэтому для осуществления законной деятельности банков и работы данных организаций в правовом поле, сами банковские структуры, прежде всего, должны проводить мониторинг за операционной деятельностью, осуществляя постоянный контроль всех ключевых показателей, отчетности и правовых действий сотрудников. Именно кредитные организации и в целом банковский сектор является той структурой, которая наиболее привлекательная для криминальных элементов, которые с помощью денежных переводов и другими способами пытаются легализовать средства, полученные преступным путем.

Законодательная база РФ в области ПОД/ФТ состоит из множества законно и подзаконных актов, ратифицированных Конвенций и других юридически значимых документов. Кроме того, национальная система государственного контроля и надзора представлена в основном такими органами, как Федеральная служба по финансовому мониторингу (Росфинмониторинг) и Банк России, а также другими организациями.

Банк России проводит нормативно-методологическую работу в области ПОД/ФТ, разрабатывая и издавая соответствующие положения, указания и письма, регулирующие исполнение кредитными организациями требования антилегализационного законодательства.

Представляется, что главная цель законодательно-правовой базы в области регулирования финансово-кредитной системы состоит в создании комплексной системы контроля, которая будет нацелена на предупреждение случаев легализации доходов, полученных преступным путем, и финансирования терроризма.

Так, Закон №115-Ф3, в целях создания такой комплексной системы государственного надзора и обеспечения её прозрачности, и с учетом специфики деятельности банковских структур, наделил кредитные организации основными функциональными обязанностями, дополнив их специальными обязанностями.

Характеристика и описание основных обязанностей банковских структур вытекает из самой сути финансовых организаций, которые предназначены для аккумулирования денежных средств и последующего их размещения в выгодных активах, то есть, обязаны работать непосредственно с наличными и безналичными денежными средствами. При этом, в категорию основных обязанностей входит осуществление процедуры идентификации клиентов, как физических, так и юридических лиц.

Наряду с основными, у кредитных организаций имеются специальные обязанности, которые также присущи только данным учреждениям и позволяют банковским структурам эффективно управлять своей финансовой деятельностью.

В рамках выполнения требований Росфинмониторинга, а также нормативно-правовых актов в области ПОД/ФТ, кредитные организации наделены обязанностью информировать контролирующие структуры об определенных финансовых операциях и сделках, которые в законодательном порядке подлежат обязательному контролю и должны быть доведены до Росфинмониторинга. Так, обязательному контролю со стороны государства подлежат следующие операции и сделки.

1. Все банковские операции, включая переводы и оформление депозитных счетов, а также сделки с движимым имуществом, которые официально зарегистрированы в установленном законом порядке на сумму шестьсот тыс. руб. и более.

2. Все сделки с недвижимостью, которые официально зарегистрированы в установленном законом порядке на сумму три млн руб. и более.

3. В случае, если некоммерческие организации получают от иностранных компаний любые финансовые активы на сумму от ста тыс. руб. и более.

4. Все банковские операции организаций, деятельность которых связана непосредственно с обороноспособностью и безопасностью нашей страны, а также в соответствии со ст.1 №213-ФЗ. 
Таким образом, кредитные организации, основной сферой деятельности которых являются операции с денежными средствами, часто становятся объектом воздействия со стороны криминальных групп и отдельных личностей, которые с помощью денежных переводов и другими способами пытаются легализовать средства, полученные преступным путем.

Банки обладают широкими возможностями для выявления подозрительных операций. Поэтому осуществляя свою деятельность в сфере противодействия легализации (отмыванию) доходов, полученных преступным путем, и финансирования терроризма, они выполняют основные и специальные обязанности, реализуя свои основные функции - выявление и направление в Росфинмониторинг и другие государственные надзорные органы сведения об операциях, подлежащих обязательному контролю и сомнительных операций.

Помимо вышеназванных функций Банк России продолжает проводить нормативнометодологическую работу в области ПОД/ФТ, разрабатывая и издавая соответствующие положения, указания и письма, регулирующие исполнение кредитными организациями требования антилегализационного законодательства.

1. Иванов, А.В. Предотвращение финансового мошенничества в целях противодействия легализации преступных доходов / А.В. Иванов // Управленческий учет. - 2016. —№2. —C. 86-93.

2. Лебедева, А.А Противодействие использованию банковской системы в целях легализации доходов, полученных преступным путем / А.А. Лебедева // Безопасность бизнеса. 2014. — № 3. - С. 37-40.

3. Об открытии банковских счетов и аккредитивов, о заключении договоров банковского вклада хозяйственными обществами, имеющими стратегическое значение для оборонно-промышленного комплекса и безопасности Российской Федерации, и внесении изменений в отдельные законодательные акты Российской Федерации: Федеральный закон от 21 июля 2014 г. № 213-Ф3 (в ред. от 27.12.2019) // Собрание законодательства РФ. - 2014. — №30. - ст.4214.

4. Шохин, С.О. Проблемы правового обеспечения борьбы с легализацией незаконно полученных доходов в Евразийском экономическом союзе // Юрист. — 2018. —№1. — С. 53.

\section{Земсков И.Н. \\ Генезис уголовной ответственности за побег из места лишения свободы, из-под ареста или из-под стражи в России}

Владимирский юридический институт Федеральной службы исполнения наказаний (Россия, Владимир)

doi: 10.18411/trnio-11-2021-240

\section{Аннотация}

Статья посвящена истории развития института уголовной ответственности за побег из места лишения свободы, из-под ареста или из-под стражи в России. Автором проводится анализ нормативных правовых актов, отражающих уголовную ответственность за побег из мест заключения и принудительной изоляции в период с 1845 года по настоящее время. В ходе анализа нормативной базы дореволюционной России, советского государства и современной России автор дает вывод, что история развития института уголовной ответственности за побег позволяет выделить три этапа развития.

Ключевые слова: побег из-под стражи, из мест заключения, уголовная ответственность, история развития, принудительная изоляция, колонии-поселения, исправительно-трудовой лагерь.

\section{Abstract}

The article is devoted to the history of the development of the institution of criminal responsibility for escape from a place of imprisonment, from arrest or from custody in Russia. The author analyzes the normative legal acts reflecting the criminal responsibility for escape from places of detention and forced isolation in the period from 1845 to the present. In the course of analyzing 